\title{
FTIR Spectral Analysis \& Physico-Chemical Studies on Some L. Arginine Salts in Non-Aqueous Solution at Various Temperatures
}

\author{
Kannagi .K ${ }^{1}$, Jasmine Vasantharani . $\mathbf{E}^{2}$ \\ ${ }^{1}$ PG Department of Physics - Cauvery College for Women, Trichy, Tamil Nadu, India \\ ${ }^{2}$ PG \& Research Department of Physics - SeethaLakshmi Ramasamy College, Trichy, Tamil Nadu, India
}

\begin{abstract}
The ultrasonic velocity measurement of liquid plays an important role in the study of molecular systems. The present work deals with the molecular interaction studies on some amino acids in non-aqueous solutions at various temperatures. From the measured parameters such as velocity, density, viscosity and some derived parameters like internal pressure, free volume, Rao's constant and Wada's constant are calculated. The structural changes occurring in the solution are envisaged through the FTIR study of L-Arginine derivatives in polar solvent. From the study the existence of interactions are confirmed and the diagnostic bonds observed at certain frequencies are assigned to the carbonyl stretch present is identified.
\end{abstract}

Keywords: Internal pressure, Free volume, Molecular interactions, FTIR Spectral analysis

\section{Introduction}

Ultrasonic velocity and its related properties have been extensively used to study physico-chemical behavior and molecular interaction occurring in the solutions. The internal pressure of a solution is a single factor which appears to vary due to all the internal interactions like solvation, ionsolvent interactions, quantum mechanical forces of dispersion and dielectric constant effect [1].The present study involves the analysis of amino acid derivatives in nonaqueous medium, formamide. Acoustic, thermodynamic parameters have been studied from very low temperature to high temperature at different molalities. The ultrasonic velocity data combined with density and viscosity provide the standard means for determining the internal pressure, free volume, acoustical parameters such as Rao's constant, Wada's constant and van der Waal's constant. Arginine is found in a wide variety of food sources such as wholewheat, nuts, seeds, peanuts, brown rice, popcorn, soya, raisins, chocolate, almonds, and oatmeal [2].L-Arginine mono hydrochloride is commonly used in cell culture media and drug development [3].L-Arginine methyl ester di hydrochloride increases nitric oxide (NO) production and it also acts as a vasodilator, allowing more blood to flow in muscle tissues, thereby increasing the pump from oxygen and nutrients and delivered where they are needed[4].

\section{Experimental Details}

\section{Experimental Technique}

Solutions of the sample of different concentrations are prepared with AR grade salt. It is used without further purification. The solution is studied at different concentrations $(0.001,0.01,0.05,0.1,0.2) \mathrm{mol}$. d.m ${ }^{-3}$ with an accuracy of $0.0001 \mathrm{gm}$ is maintained. The density of the solutions is determined using $25 \mathrm{ml}$ specific gravity bottle, using the thermostatic bath with a compressor unit. A Cannon Fenske viscometer $(10 \mathrm{ml})$ was used for the viscosity measurements. Variable bath interferometer having a frequency of $2 \mathrm{MHz}$ (Mittal Enterprises, New Delhi) with overall accuracy of $0.1 \%$ was used for velocity measurements. With the high purity (99\%) the samples are purchased from siscom research laboratories, Mumbai. The samples are measured using an electronic balance precise to 0.0001gm.Ultrasonic velocity $(\mathrm{u})$ is measured with a variable path interferometer $\left(2 \mathrm{MH}_{\mathrm{Z}}\right)$ with an accuracy of $\pm 2 \mathrm{~m} / \mathrm{s}$. The density ( $\rho)$ measurement is made with an accuracy of $\pm 0.001 \mathrm{gm}$. FTIR spectrum of these solution were recorded in the region of $4000-400 \mathrm{~cm}-1$ using (PERKIN ELMER) model SPECTRUM RXI FTIR spectrometer.

The following formulae are used for the computation of Internal Pressure $\left(\pi_{\mathrm{i}}\right)$, Free Volume $\left(\mathrm{V}_{\mathrm{f}}\right)$, Rao's constant and Wada's constant:

Internal pressure $\quad \pi_{i}=b R T\left(\frac{k \eta}{u}\right) \frac{1}{2} \times\left(\rho^{\frac{2}{3}} / M_{e f f}{ }^{\frac{7}{6}}\right)$ atms.

Free volume $V_{f}=\left[M_{e f f} \times u / k \eta\right]^{\frac{3}{2}} c C$

Rao's constant $R=\frac{M_{\text {eff }}(U)^{1 / 3}}{\rho}$

Wada's constant $W=\frac{M_{\text {eff }}}{(\rho) \beta^{-1 / 7}}$

Where,

$\mathrm{M}_{\mathrm{eff}}$ - Effective molecular weight of the

solution in gm.u .

$\mathrm{u}$ - Ultrasonic velocity in $\mathrm{cm} / \mathrm{sec}$.

$\mathrm{K}$ - Constant equal to $4.285 \times 10^{9}$

$\eta$ - Viscosity of the solution in poise

$\mathrm{R}$ - Gas constant $\left(8.314 \times 10^{7}\right)$

$\mathrm{T}$ - Temperature

B - Cubic constant (2) 


\section{International Journal of Science and Research (IJSR) \\ ISSN (Online): 2319-7064}

Index Copernicus Value (2013): 6.14 | Impact Factor (2014): 5.611

$\rho$ - Density of the solution is gm/cc.

\section{Results and Discussions}

In the present work, the internal pressure and free volume shows an increasing trend with respect to molalities. This increasing trend in internal pressure indicates the orientation of the solvent molecules around the L-Arginine ions, which may be due to the influence of electrostatic field of ions. This behavior suggests that the presence of strong ionsolvent interaction occurs in the solution [5]. The binding of the $\mathrm{NH}_{3}{ }^{+}$group of solute into the solvent molecules introduces the greater cohesion by the electrostatic forces in the solution. Thus, the electrostriction effect brings about the shrinkage in the volume of the solvent caused by the Zwitterionic portion of the L-Arginine solution [6]. There is a dip observed at $0.05 \mathrm{~m}$ at all temperature in L-Arginine mono hydrochloride solution. Hence there is a reduction in internal pressure with increase in temperature L-Arginine mono hydro chloride exists in ionic form and it is solvated both at $\mathrm{NH}_{3}^{+}$site of guanidino group and COO'sites of solute in which the existence of Zwitterionic form to a greater extent. These results support that there is a weak ionsolvent interaction within the solution [7].However in LArginine methyl ester di hydrochloride internal pressure is to be increasing with respect to increasing molality. But at $278.15 \mathrm{k}$ and at 0.05 molality it is observed as minimum. This decrease in internal pressure shows that there is a weak solute - solvent interaction prevails in the solution which is shown in Tables 1.1-1.3 and Figure 1.(i)-1.(iii). It is also confirmed by increasing values of free volume given in tables 2.1-2.3 and figures 2.(i)-2.(iii) at low molalities and at low temperature [8].

Rao's and Wada's Constant In L-Arginine the solvent shows that there may be association taking place between the molecules in the solution [9].This behavior is exhibited by Rao's and Wada's constant (Tables 3.1-3.3 and Figures3.(i)-3.(iii) for the same system..The irregular behavior of Rao's and Wada's constants of L-Arginine mono hydrochloride system also supports that there is a molecular dissociation existing in the solution. In LArginine Methyl Ester di hydrochloride, Rao's and Wada's constants are increasing with increasing concentration and also with temperature. At 308.15k there is a dip observed at 0.01 molality. Though there is a curvilinear variation of these constant at 308.15k the noticeable deviation indicates the weakening the structure of the solvent [10]. This indicates that the structure breaking nature of the solute in the solvent [11]. These values are tabulated in the shown in tables 4.1-4.3 and Figure 4.(i)-4.(iii).Thus, the acoustical parameters, explains the nature and strength of the molecular interaction in the solution[12].

In the FT-IR spectra of formamide and for the samples, the presence of various vibrational frequencies have been identified and analyzed based on shifts in frequencies. LArginine, can exist in two forms i.e., charge solvated (CS) and salt bridge (SB) as in (Figure 6.1 and 6.2).

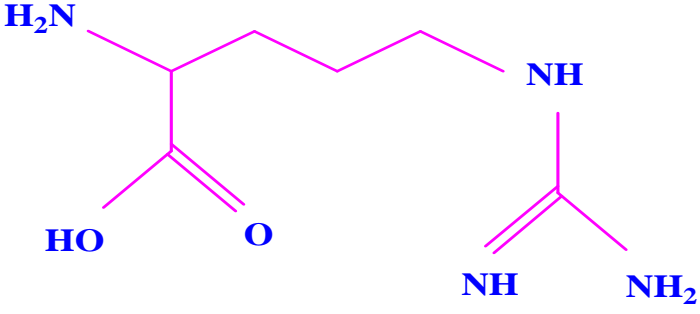

Figure 6.1: Non - Zwitterion -Neutral (Charge Solvated CS)

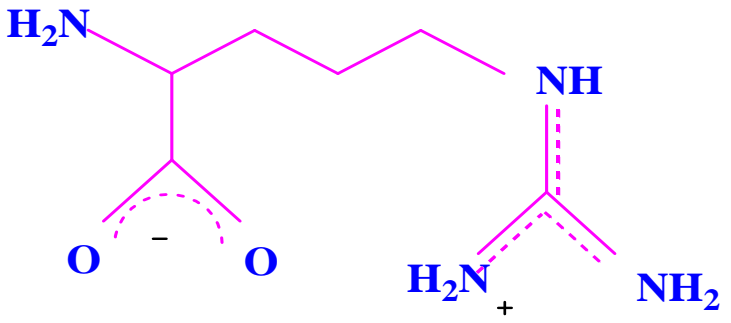

Figure 6.2: Zwitterion (Salt Bridge - SB)

These FT-IR spectral results of L-Arginine with formamide indicate the formation of $\mathrm{H}$-bands between $\mathrm{NH}_{2}$ group of formamide and guanidino group of L-Arginine. The Zwitterionic form of L-Arginine is solvated by both enolic form (monomer) and dimeric forms of formamide. The amino acid exists in both neutral and Zwitterionic forms [13].

In L-Arginine mono HCL system the shifts are small compared to L-Arginine. Hence solvation is of weak type [13].This indicates the existence of enolic (neutral) form and amide form. Thus solvation is through weak H-bonding results in neutral form (Fig. 6.3). This may be due to dipoledipole interaction [14].

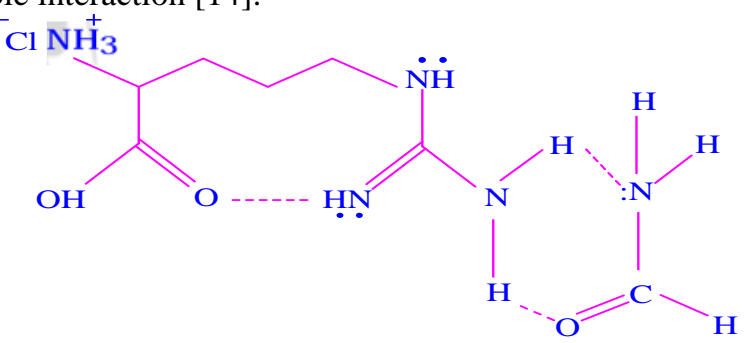

Figure 6.3: Neutral form of L-Arginine mono hydrochloride

In the L-Arginine methyl ester di hydrochloride sample there is no acidic $\mathrm{COOH}$ proton but it has an $\mathrm{O}-\mathrm{CH}_{3}$ group in the place of $\mathrm{O}-\mathrm{H}$. Therefore it has a free $\mathrm{C}=\mathrm{O}$ group and not having $\mathrm{COO}^{-}$group compared to L-Arginine and exist in neutral form (figure 6.4)[15].

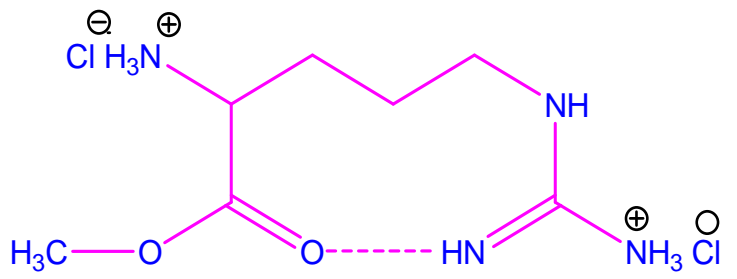

Figure 6.4: Neutral form of L-Arginine methyl ester di hydrochloride 


\section{International Journal of Science and Research (IJSR) \\ ISSN (Online): 2319-7064 \\ Index Copernicus Value (2013): 6.14 | Impact Factor (2014): 5.611}

A new peak arrived at $2405 \mathrm{~cm}^{-1}$ indicates solvation at this site by formamide, resulting in the structure (Figure 6.5) for the charge solvated

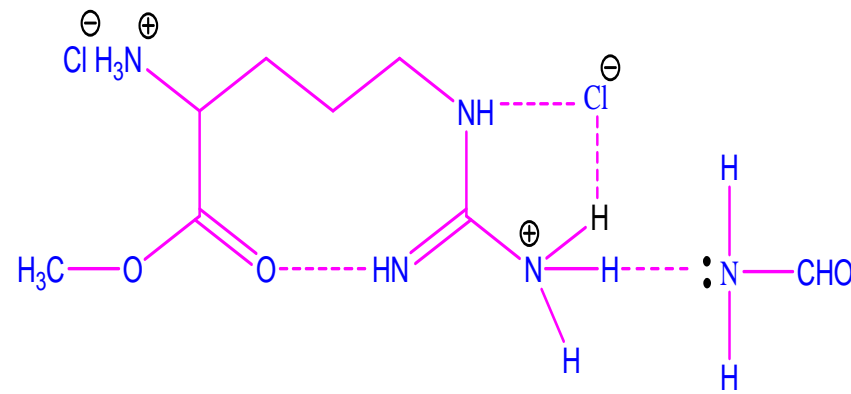

Figure 6.5: Charge solvated form of L-Arginine methyl ester di hydrochloride

The dilution studies thus indicate the appearance of new peaks at $2405 \mathrm{~cm}^{-1}$ and disappearance of $1442 \mathrm{~cm}^{-1}$ peak (C$\mathrm{N}$ Stretch \& NH bending). These changes can be accounted by considering solvation only at guanidino group. The broadening of $\mathrm{NH}_{2}$ stretching vibration of the solvent indicates binding of the amino acid ester to the $\mathrm{NH}_{2}$ group of formamide [16]. It exists as mirror image form at chiral center $\left(\mathrm{CH} \mathrm{COO} \mathrm{CH}_{3}\right)$ [17] depicted in (Figs.6.6a and 6.6b) as inferred from the FT-IR spectrum Figure 5.1- 5.7..

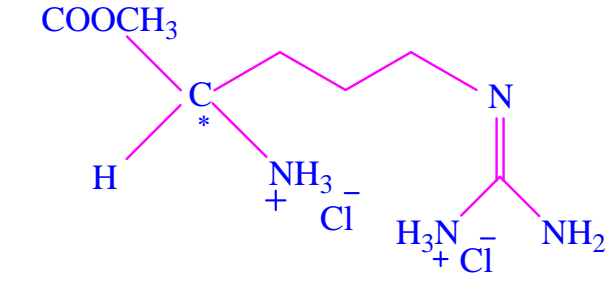

Figure 6.6a

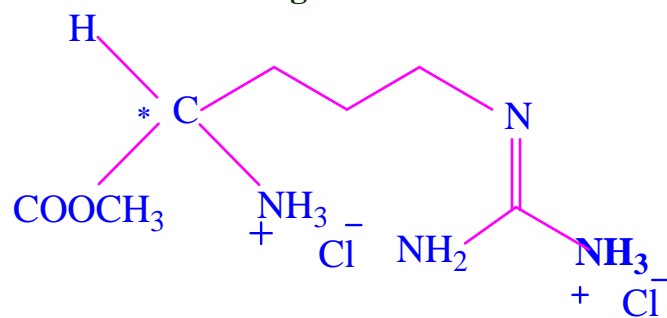

Figure 6.6b: Mirror images of L-Arginine methyl ester di hydrochloride

\section{Conclusion}

The thermodynamic and acoustic studies confirm the hydrophilic interactions occurring between the Zwitterionic center of L-Arginine and Carbonyl group of formamide. These results support that there is a weak ion-solvent interaction within the solution. The behavior in internal pressure suggests that the intermolecular hydrogen bonding exists in the amino acid moiety [18].These result shows weak-solute-solvent interactions prevail in the solution. The Zwitterionic form of L-Arginine is solvated by both enolic form (monomer) and dimeric forms of formamide.

\section{References}

[1] Gnanamba S, RamachandraRao B, Ind J Pure \&ApplPhy, 11 (1973) 99.

[2] Gokce N, Myer B, Journal of Nutrition, 134 (2004) 2807-2811.

[3] Takeshi Naito, Hiroshi Irie, Abcouwer S F, Kazuko Tsujimoto, Keikolkeda, International J Mol Medicine, 23 (2009) 495-499.

[4] Karapetyan H A, Antipin M Yu, Sukiasyan R P, Petrosyan AM, J MolStruc, 831 (2007) 90-96.

[5] Andrew P J, Myer B, Cardiovascular Research 43 (1999) 521-531.

[6] Devlin T M, Textbook of Biochemistry with Clinical Correlations, 5th ed Wiley-Liss (New York) 97 (2002) 791- 871.

[7] Jasmine Vasantha Rani E, Kannagi K, Padmavathi R, Proceedings of NSA, Bhandelkand University, Jhansi (UP), 17th-19th November, Appl Ultrasonic, (2012) $102-110$.

[8,9] Jasmine Vasantha Rani E, Kannagi K, Padmavathi R, Radha N, Proceedings of NSA, Bhandelkand University, Jhansi (UP), 17th-19th November, Acoustic waves, 1 (2012) 410 - 417.

[10] Jasmine Vasantha Rani E, Kannagi K, Padmavathi R, Radha N, Proceedings of National symposium on Acoustics, National physical Laboratory -New Delhi, 46 (2013) 410-414.

[11] Santhakumari S, Padmavathi R, Jasmine Vasantha Rani E, International Soc Socio Techno Welfare - J ApplPhys, 4 (2013) 53-60.

[12] Sujatha S, Padmavathi R, Jasmine Vasantha Rani E, International J Phys Appli, 5 (2013) 109-114.

[13] Solachi V, Ambika R, J AcousSoc India, 34 (2005) $207-$ 209.

[14] Palani R, Jayachitra K, Ind J Pure \&ApplPhys, 46 (2008) 251.

[15, 17]Jasmine Vasantha Rani E, Kannagi K, Padmavathi R, Radha N, Proceedings of National Conference on EXFOVIS, Nagarcoil 1st\&2nd September 34 (2011) $402-408$

[18] Kannagi K, Jasmine Vasantha Rani E, Padmavathi R, Radha N, International J Current Res \& Rev, 4 (2012) $156-166$.

[19] Jasmine Vasantha Rani E, Kannagi K, Padmavathi R, Radha N, J Basic \& ApplPhys, 3 (2012) 96 - 101. 


\section{International Journal of Science and Research (IJSR) \\ ISSN (Online): 2319-7064}

Index Copernicus Value (2013): 6.14 | Impact Factor (2014): 5.611

INTERNAI PRESSURE (atm)

Figure 1. (i) L-ARGININE

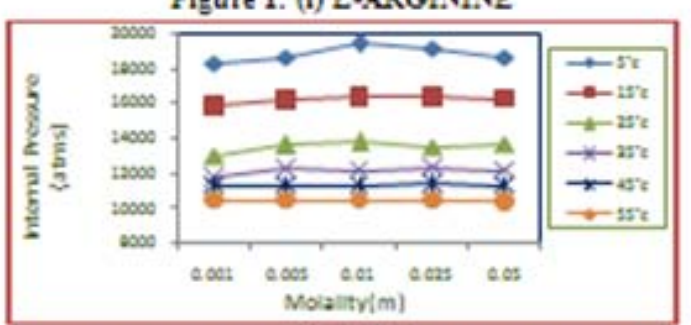

Figure 1,(ii)L-ARGININE MONOHYDROCHLORIDE

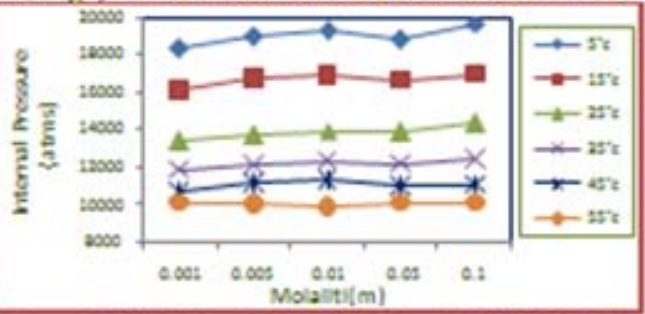

Figure 1,(iii)10 L-ARGINTNE METHYZ ESTER DIHYDROCHLORIDE

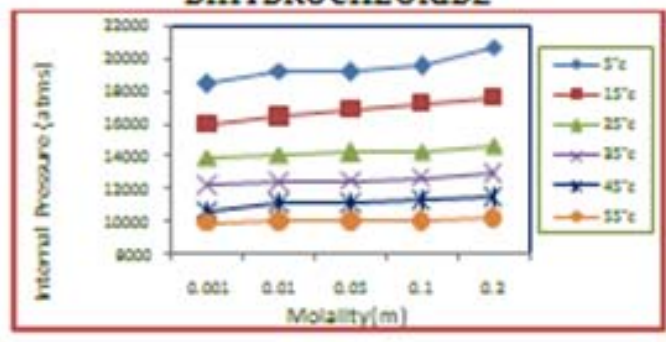

RAO'S CONSTANT

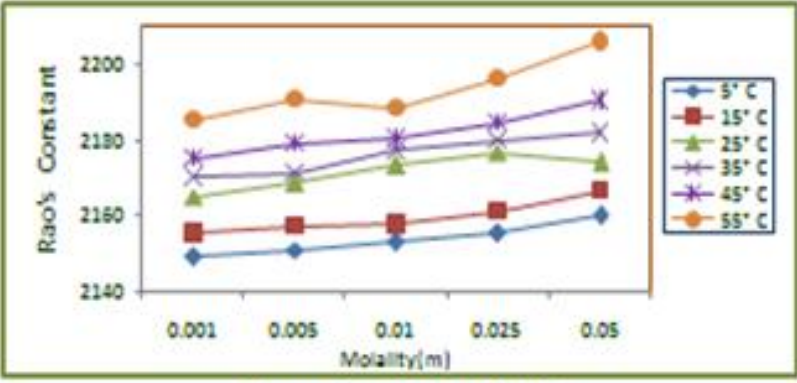

Figure 3, (i) L-ARGININE

Figure 3. (ii)L-ARGININE MONOHYDROCHLORIDE

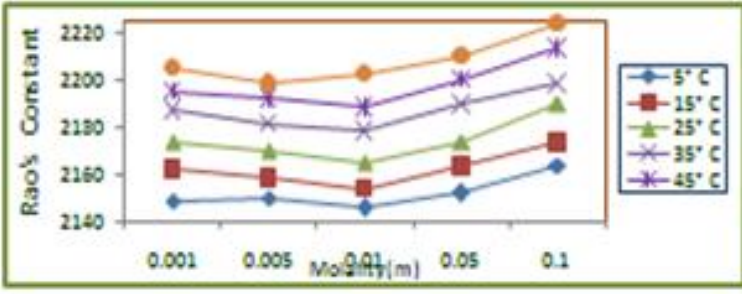

Figure 3. (iii)L-ARGININE METHYL ESTER DIHYDROCHLORIDE

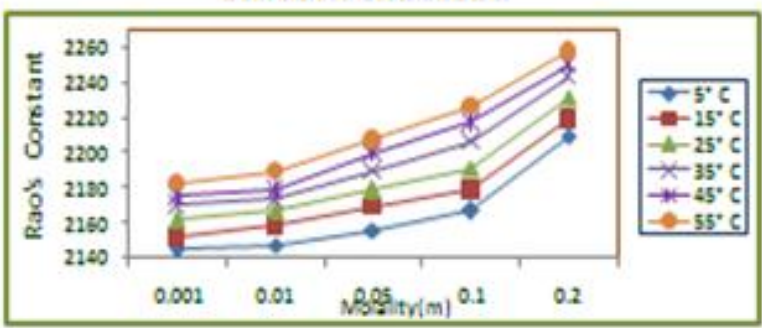

FREE VOLTME (CC)

Figure 2. (i) 15 L-ARGININE

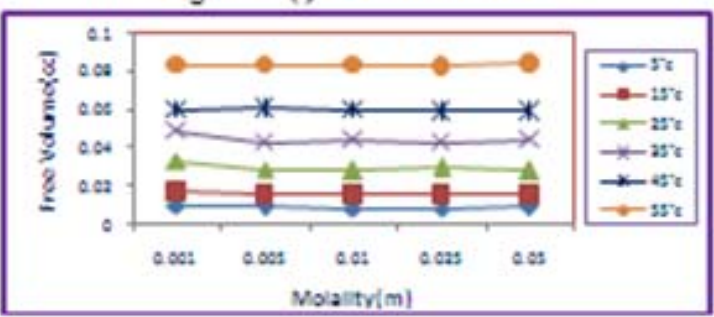

Figure 2. (ii) 16 L-ARGININE MONOHYDROCHLORIDE

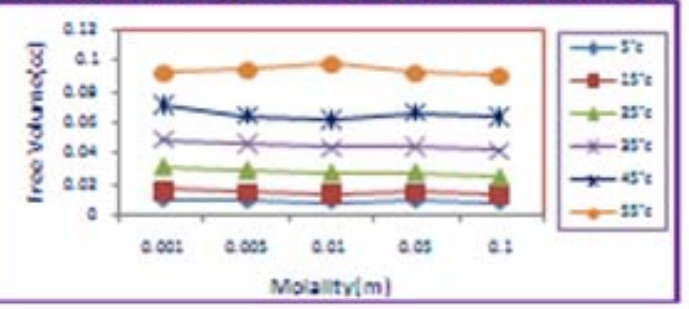

Figure 2, (iii) L-ARGININE AETHYL ESTER DIHYDROCHLORIDE

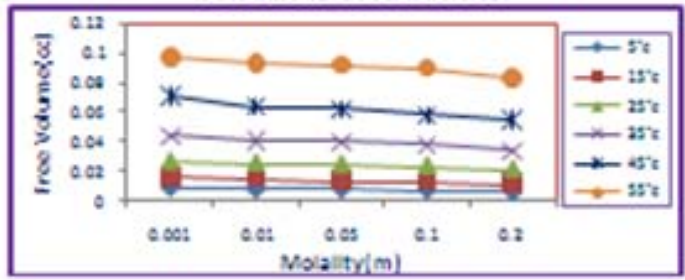

WADA'S constant

Figure 4, (i) L-ARGININE

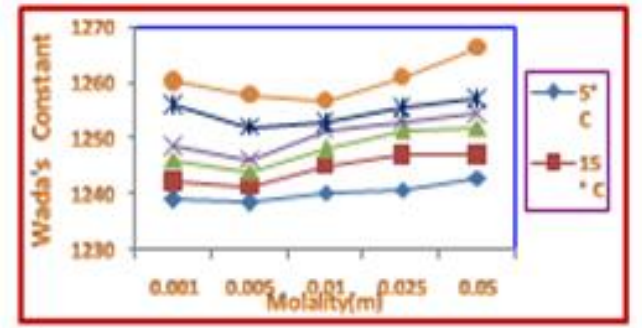

Figure 4. (ii) L-ARGLNINE MONOHYDROCHLORIDE

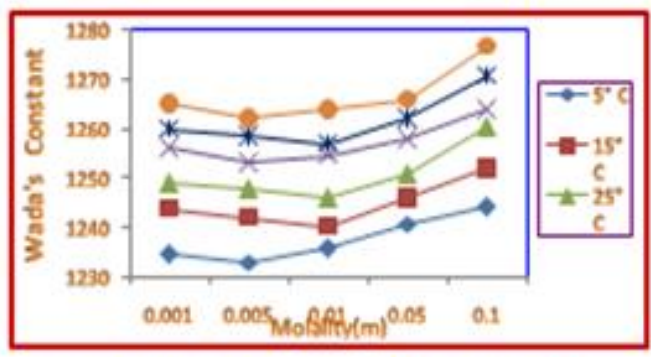

Figure 4.(iii) L-ARGINTNE METHYL ESTER DIHYDROCHLORIDE

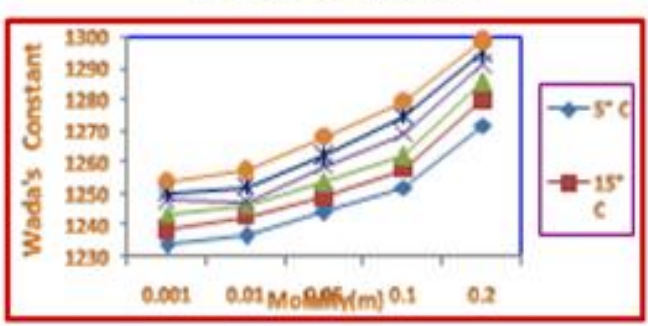

Volume 5 Issue 3, March 2016 www.ijsr.net 


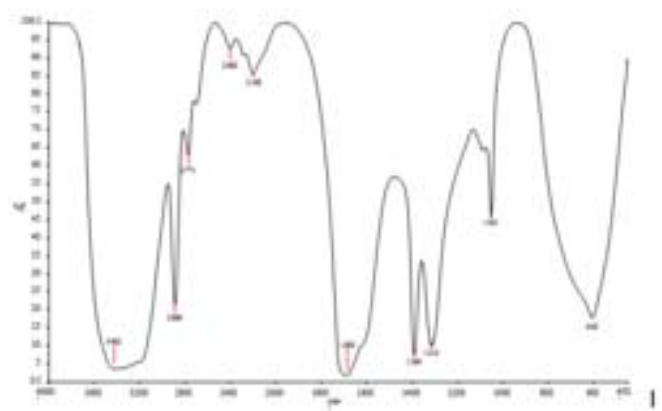

Figure 5.1: FT IR Spectrum of formamide

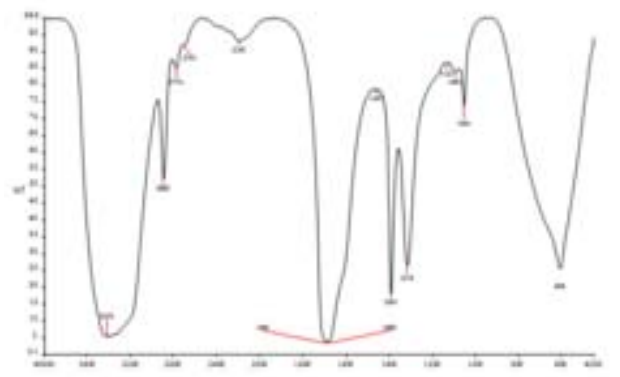

Figure 5.3: FT IR Spectrum of L-Arginine

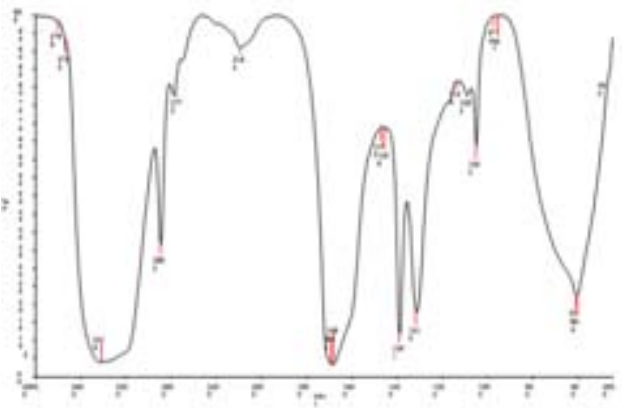

Figure 5.5: FT IR Spectrum of L-Arginine mono hydrochloride (Saturation molality)

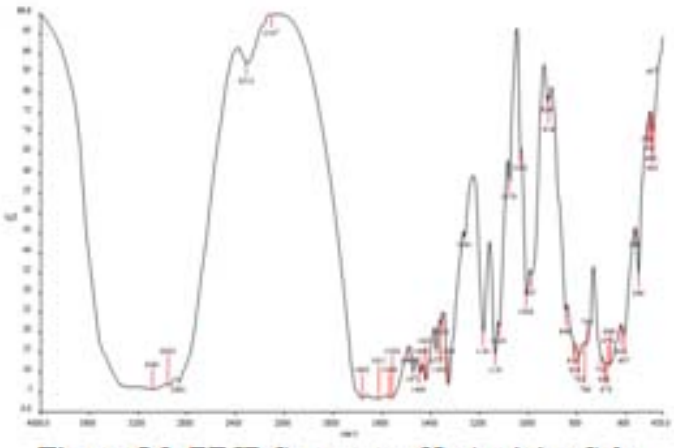

Figure 5.2: FT IR Spectrum of L-Arginine Salt

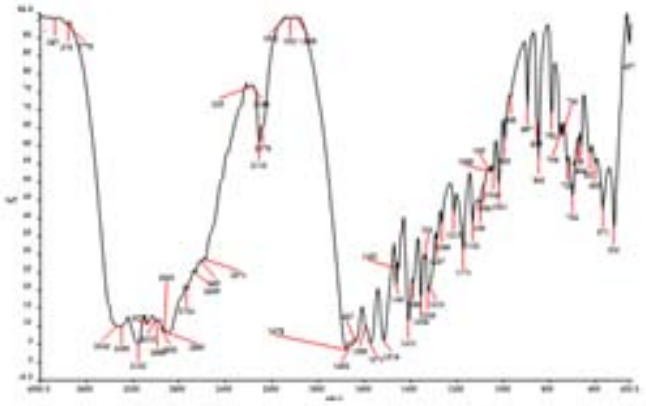

Figure 5.4: FT IR Spectrum of L-Arginine (Saturation molality)

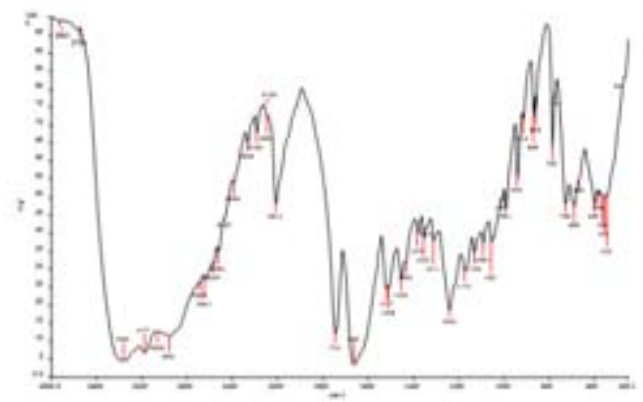

Figure 5.6: FT IR Spectrum of L-Arginine methyl ester dihydrochloride salt

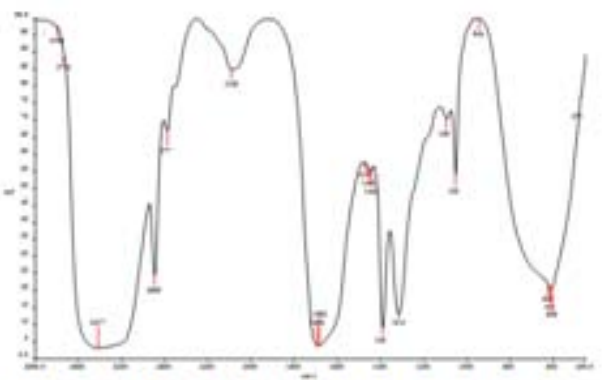

Figure 5.7: FT IR Spectrum of L-Arginine methyl ester dihydrochloride (Saturation molality) 


\section{International Journal of Science and Research (IJSR) ISSN (Online): 2319-7064}

Index Copernicus Value (2013): 6.14 | Impact Factor (2014): 5.611

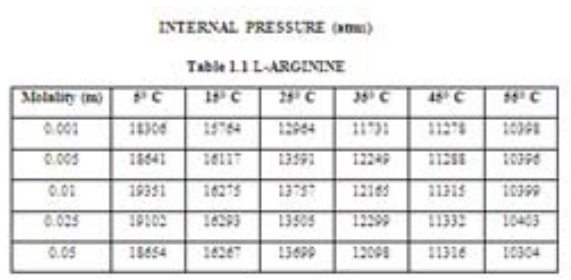

\begin{tabular}{|c|c|c|c|c|c|c|}
\hline \multicolumn{7}{|c|}{ 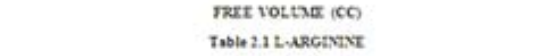 } \\
\hline Hetalieg (m) & FC & $16 \mathrm{CC}$ & $26 \mathrm{C}$ & 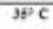 & $\mathrm{AS}^{\circ} \mathrm{C}$ & $590 \mathrm{C}$ \\
\hline 6061 & 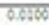 & 6059 & 6.851 & 60,044 & Q. तबत & रूक्षम \\
\hline 6005 & 8.6S: & 0.0181 & 6.059 & O60433 & $8.68 \%$ & क्षा? \\
\hline 6.9 & 80055 & 00159 & 6.6413 & 60443 & $600 \%$ & 6003 \\
\hline Q6OS & 0.001 & 0.055 & 0.051 & 0.048 & O.65 & 60035 \\
\hline 0.8 & D.05\% & 0.0191 & 0.054 & $0.04+4$ & Q,6डH & 0.064 \\
\hline
\end{tabular}

\begin{tabular}{|c|c|c|c|c|c|c|}
\hline \multicolumn{7}{|c|}{ 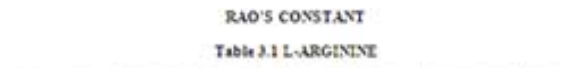 } \\
\hline Thelality (m) & $F C$ & $16 \mathrm{C}$ & $25 \mathrm{C}$ & $38^{\circ} \mathrm{C}$ & $4 \$ \mathrm{C}$ & $56^{\circ} \mathrm{C}$ \\
\hline $6.60 !$ & $21+3$ & 755 & 2105 & $7 \%$ & 25 & 245 \\
\hline 0.005 & 211 & 2157 & 2106 & 214 & $2 \%$ & 201 \\
\hline 6.61 & 25 & 2191 & 213 & मन & 915 & 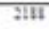 \\
\hline 6.89 & 215 & मबा & 218 & 2180 & 75 & $2 \mathrm{Ha}$ \\
\hline 0.09 & 26 & $2 \theta^{\circ}$ & 217 & IIII & मझ & मूल \\
\hline
\end{tabular}

\begin{tabular}{|c|c|c|c|c|c|c|}
\hline Stataling fal & FC & LifC & $20 \mathrm{C}$ & SEC & $\triangle P C$ & \$एव \\
\hline 0.001 & 152\% & IOWA & Ij3: & IIt) & TOWE: & 1601 \\
\hline 0.005 & 18512 & 1607 & 13626 & 12002 & 71002 & 60023 \\
\hline 0.01 & Wस\% & TERA & IPSO & 12934 & TISE & Wक्त \\
\hline 8.05 & 157? & 565 & 13644 & IISSO & IMs] & 10604 \\
\hline 0.1 & 16072 & 1609 & 14345 & 1296 & 11054 & 10004 \\
\hline
\end{tabular}

\begin{tabular}{|c|c|c|c|c|c|c|}
\hline Solation (ina) & FC & $15 \mathrm{C}$ & $2 \mathrm{FC}$ & ग्रC & $4 F \mathrm{C}$ & प्र०C \\
\hline $606 !$ & 6.6180 & 60162 & 00012 & 604015 & $607 \%$ & 6.0914 \\
\hline क्षक & 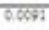 & 0.0145 & कबक्तन & 0.6594 & 0.0015 & बख़ा: \\
\hline 601 & 80015 & 80145 & 0.0273 & 60426 & 6.0651 & Qब्रण \\
\hline 689 & 6081 & 6.612 & 60.3 & 60401 & 68Es? & $6 \mathrm{~kg}$ \\
\hline 0.1 & $0.60 \%$ & 80150 & $0 \cos 4$ & 0.0413 & 0.068 & 0.065 \\
\hline
\end{tabular}

\begin{tabular}{|c|c|c|c|c|c|c|}
\hline Wouslien (n) & FC & $15 \mathrm{C}$ & $25 \mathrm{C}$ & $35^{\circ} \mathrm{C}$ & 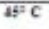 & $54 \mathrm{C}$ \\
\hline $6.60 !$ & 2149 & 216: & 2174 & भून & 2155 & 205 \\
\hline 0.005 & 2156 & $35 \pi$ & 218 & sit & मक: & 2151 \\
\hline 0.01 & 2144 & 2154 & 2185 & 3178 & 210 & 2202 \\
\hline 6.69 & 5159 & 283 & 214 & 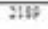 & 210 & 298 \\
\hline 6.1 & 5154 & III & IN & 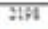 & 212 & 252 \\
\hline
\end{tabular}

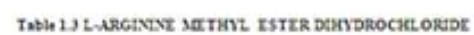

\begin{tabular}{|c|c|c|c|c|c|c|}
\hline Sholating (ci) & $5 \mathrm{C}$ & $15 \mathrm{C}$ & $25 \mathrm{C}$ & $36 \mathrm{C}$ & $A E C$ & 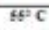 \\
\hline 0.001 & $18 \times 27$ & 150 & 12990 & $12 \times 19$ & 10702 & कOA \\
\hline 6.01 & 15239 & 16094 & 14155 & 15493 & IIII & 100095 \\
\hline 0.05 & $10 \mathrm{~T}$ & IEB? & La:15 & 18602 & 11120 & 16037 \\
\hline 0.1 & कलक & $15 \%$ & IDM & $128+6$ & 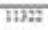 & 160\% \\
\hline 0.2 & 5\% & ग6: & $1+64$ & $25 \% 4$ & $11+45$ & $1621^{-1}$ \\
\hline
\end{tabular}

TAW 2.3 L WRGINTE METHYL ESTER DCHNDKOCHLORRDE

\begin{tabular}{|c|c|c|c|c|c|c|}
\hline Matalicy (ini) & $F C$ & $3{ }^{\prime} \mathrm{CC}$ & $2 F C$ & $20 \mathrm{C}$ & $4 F C$ & $\mathrm{MPC}$ \\
\hline 6001 & 0.005 & 60105 & 8.027 & $0.04+4$ & 6.075 & ब0लन \\
\hline 601 & 6,6084 & 6015: & 60200 & 6.642 & 60051 & $6.0 \% 5$ \\
\hline 6.65 & 0.698 & 0.011 & 6.6\%1 & 0.654 & $6 \times 95$ & रूल्जाक \\
\hline 8.1 & 8.0000 & 6012 & 0.0244 & 0.0954 & 60012 & $6.80:$ \\
\hline 0.2 & 0.064 & 0.0110 & 0.0211 & 0.0946 & 0.0457 & O.c6s \\
\hline
\end{tabular}

\begin{tabular}{|c|c|c|c|c|c|c|}
\hline Solality (m) & $\Rightarrow \mathrm{C}$ & $15=\mathrm{C}$ & $25=\mathrm{C}$ & $35 . \mathrm{C}$ & $A g=\mathrm{C}$ & $4 \xi^{2} \mathrm{C}$ \\
\hline $0.00 !$ & 2145 & 2152 & 262 & $21 \%$ & 213 & 2201 \\
\hline 6.61 & $\$ 243$ & 2151 & 2967 & $\$ 14$ & $2 \%$ & 24 \\
\hline 805 & 3156 & 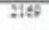 & $2 \%$ & 915 & 200 & स०० \\
\hline 6.1 & 215 & $21 \%$ & 2101 & 250 & 2217 & 2227 \\
\hline 0.2 & 2910 & $22 \%$ & 292 & 2943 & 230 & 259 \\
\hline
\end{tabular}

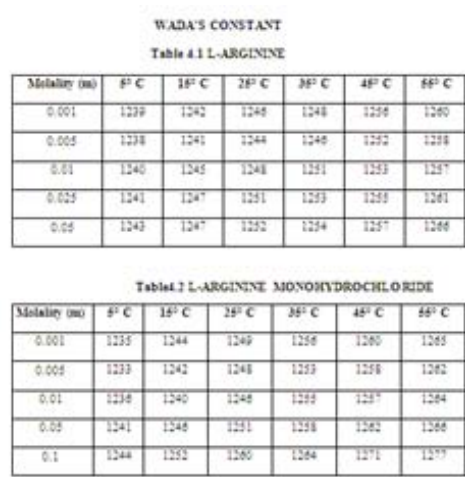

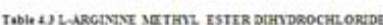

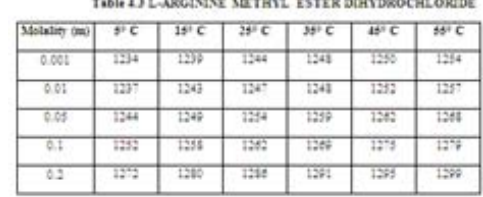

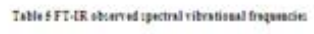
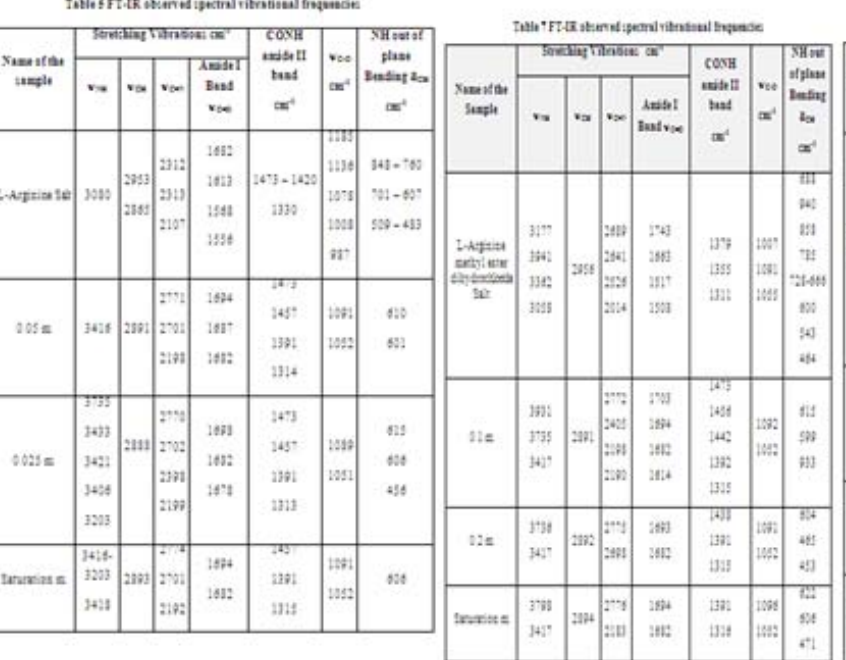

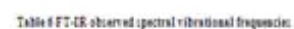

\begin{tabular}{|c|c|c|c|c|c|c|c|}
\hline \multirow[b]{2}{*}{ 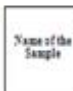 } & \multicolumn{4}{|c|}{ 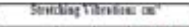 } & \multirow{2}{*}{$\begin{array}{l}\text { cosh } \\
\text { mith } \\
\text { matal } \\
\text { \% }\end{array}$} & \multirow[b]{2}{*}{$=$} & \multirow{2}{*}{ 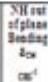 } \\
\hline & " & $\mathrm{s}$ & $\times$ & $\begin{array}{l}\text { Melibt } \\
\text { Busvom }\end{array}$ & & & \\
\hline 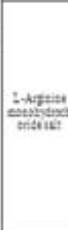 & 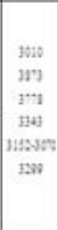 & $\begin{array}{l}m \\
m \\
m \\
m \\
m\end{array}$ & 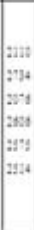 & $\begin{array}{l}195 \\
195 \\
\text { ins } \\
\text { ins } \\
\text { was } \\
\text { is }\end{array}$ & 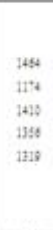 & 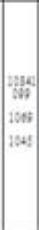 & 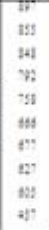 \\
\hline 781: & $\begin{array}{l}34 \\
34 \\
347\end{array}$ & $a n:$ & $\mid$\begin{tabular}{l}
$\cdots$ \\
\hdashline
\end{tabular} & $\begin{array}{l}\text { in } \\
\text { ans }\end{array}$ & 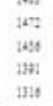 & $\mid \begin{array}{l}\sin \\
\operatorname{sen} 2\end{array}$ & 48 \\
\hline $11=$ & $\begin{array}{l}174 \\
143\end{array}$ & $2 B$ & $\begin{array}{l}\cdots \\
\cdots\end{array}$ & $\begin{array}{l}\text { In: } \\
\text { in: }\end{array}$ & $\begin{array}{l}\text { wh } \\
\text { its? } \\
\text { ins } \\
\text { int }\end{array}$ & $\mid \begin{array}{l}100 \\
100\end{array}$ & $n^{*}$ \\
\hline traxime & $\begin{array}{l}1 \% \\
344\end{array}$ & $a n$ & \begin{tabular}{l}
$: \cdots 4$ \\
\hdashline 44
\end{tabular} & $\begin{array}{l}3: 4 \\
\mathrm{sn}\end{array}$ & $\begin{array}{l}\text { 135 } \\
1354 \\
1346\end{array}$ & $\mid \begin{array}{l}106 \\
105\end{array}$ & $\begin{array}{l}111 \\
44 \\
44\end{array}$ \\
\hline
\end{tabular}

Volume 5 Issue 3, March 2016 www.ijsr.net 